\title{
Article
}

http://dx.doi.org/10.11646/phytotaxa.243.1.5

\section{Typification of names in the genus Anaphyllum (Araceae)}

\author{
M. SIVADASAN ${ }^{1, *}$, V. ABDUL JALEEL ${ }^{2}$, P. C. BOYCE ${ }^{3}$, A. H. ALFARHAN ${ }^{1}$, M. A. EL-SHEIKH ${ }^{1}$ \& S. M. AL- \\ OBAID $^{1}$ \\ ${ }^{1}$ Department of Botany \& Microbiology, College of Science, King Saud University, P. O. Box 2455, Riyadh-11451, Kingdom of Saudi \\ Arabia. \\ ${ }^{2}$ Department of Botany, Sir Syed College, Taliparamba, Kannur, 670 142, Kerala, India. \\ ${ }^{3}$ Institute of Biodiversity and Environmental Conservation (IBEC), Universiti Malaysia Sarawak, 94300-Samarahan, Sarawak, \\ Malaysia. \\ "Corresponding authorE-mail: drmsivadasan@gmail.com
}

\begin{abstract}
The little-known and small genus Anaphyllum (Araceae), represented by only two species endemic to India, namely $A$. beddomei and $A$. wightii, has remained without correctly designated types. Their syntypes are recognized and the names are here typified. The correct bibliographic reference to the protologue of $A$. wightii is provided for the first time.
\end{abstract}

Key words: Endemic, Lasioideae, lectotypes, syntypes, types

\section{Introduction}

The genus Anaphyllum Schott (1857: 126) (Araceae) is endemic to India with only two species confined to South India on the Western Ghats in Tamil Nadu, Kerala and Karnataka states. Anaphyllum was published by Schott with the only species Anaphyllum wightii Schott (1857: 127) based on specimens collected by Wight in 1835 from Courtallum in the present Tamil Nadu state, India. Engler (1911) added Anaphyllum beddomei Engler (1911: 26) to this then-monotypic genus based on specimens collected by Major R.H. Beddome in 1873 from Tinnevelly Hills of former Malabar and Travancore Province, now in Tamil Nadu state, India.

During revisionary work of the genus and also while updating the checklist of Araceae as part of a project on preparation of a 'Checklist of plants of India', it was noticed that both the species, Anaphyllum beddomei and A. wightii appear to be as yet untypified and are investigated here.

\section{Typification}

Anaphyllum beddomei Engler, Pflanzenr. Heft 48 (IV. 23C): 26. 1911.

Lectotype (designated here):- INDIA. Tinnevelly Hills, Prov. Malabar \& Travancore, no date, R.H. Beddome 7869 or 7873 (BM!, BM000958557). Fig. 1

Other specimens studied:-INDIA. Tinnevelly Hills, 1873, R.H. Beddome s.n. (K!, K000499256); Anamallays, 4000 ft. elev., 1873, R.H. Beddome s.n.(CAL!, CAL0000027004); Prov. Malabar \& Travancore, R.H. Beddome 217 (BM!, BM000957455).

In the protologue of Anaphyllum beddomei (Pflanzenr. Heft 48 (IV. 23C): 26-28. 1911), Engler (1911) cited specimens as "Beddome n. 7869-7873-Herb. Hort. Calcutta, Herb. Brit. Mus.", which can be assumed to refer to a total of five specimens numbered consecutively from 7869 to 7873 . In the absence of indicating a single specimen as the type, all of the specimens cited in the protologue are to be treated as syntypes (Art. 9.5 of ICN, McNeill et al. 2012).

There are two specimens in the herbarium of The Natural History Museum, London (BM), both are probably syntypes, and one among them (BM000958557) bears a label reading "Prov. Malabar \& Travancore: Tinnevelly Hills. 